\title{
Bioeconomic analysis of the effects of modifying the trawl extension piece with T90 netting
}

\author{
Iván Sola, Francesc Maynou \\ Institut de Ciències del Mar, CSIC, Pg. Marítim de la Barceloneta, 37-49, 08003 Barcelona, Spain. \\ (IS) E-mail: ivansolaccmar@gmail.com. ORCID iD: http://orcid.org/0000-0003-2972-614X \\ (FM) (Corresponding author) E-mail: maynouf@icm.csic.es. ORCID iD: http://orcid.org/0000-0001-7200-6485
}

\begin{abstract}
Summary: We assessed the effect of the European discards ban on the profitability of bottom trawlers in a case study fishery (GSA06, NW Mediterranean) in the transition period 2017-2018, when the species that characterize the fishery, viz. hake and red mullet, fall under the discards ban. We used the results of Sola and Maynou (2018) to simulate the adoption of a modified bottom trawl design using a T90 extension net to reduce the catches of undersize hake and red mullet. Our results show that the economic impact of the former discards brought to land on the fisheries operators is expected to be low, regardless of the possible commercial use of these unwanted catches. Furthermore, the adoption of a more selective bottom trawl design would increase the escape of undersize individuals and likely reduce fishing mortality of the target species, contributing to stock rebuilding and providing higher income to the fisheries operators in the medium to long term.
\end{abstract}

Keywords: discards ban; bottom trawl fisheries; T90 net; bioeconomic model; Mediterranean fisheries.

Análisis bioeconómico de los efectos de la modificación de la extensión de un arte de arrastre con malla T90

Resumen: Se evaluó el efecto de la prohibición de descartes sobre los beneficios económicos de la flota de arrastre del área GA06 (Mediterráneo noroccidental) en el periodo transitorio 2017-2018 durante el que las especies que caracterizan la pesquería, es decir la merluza y el salmonete, deben desembarcarse obligatoriamente. Usamos los resultados de Sola y Maynou (2018) para simular la adopción de un nuevo arte de arrastre que emplea una extensión dotada de una red de malla T90 para reducir las capturas de merluza y salmonete por debajo de la talla legal. Los resultados muestran que es de esperar que el impacto económico de las capturas que deben obligatoriamente desembarcarse para usos comerciales distintos del consumo humano sea bajo, tengan o no posible uso industrial. Al mismo tiempo, la adopción de un diseño de arte de pesca de arrastre más selectivo permitiría aumentar el escape de individuos de talla inferior a la legal y contribuir a la reducción de la mortalidad por pesca de las especies objetivo, y en último término a la reconstrucción de los stocks pesqueros, permitiendo generar mayores ingresos a los operadores pesqueros a medio y largo plazo.

Palabras clave: prohibición de descartes; pesquería de arrastre; red T90; modelo bioeconómico; pesquerías mediterráneas.

Citation/Como citar este artículo: Sola I., Maynou F. 2018. Bioeconomic analysis of the effects of modifying the trawl extension piece with T90 netting. Sci. Mar. 82S1: 27-37. https://doi.org/10.3989/scimar.04715.06A

Editor: M. Demestre.

Received: October 10, 2017. Accepted: March 14, 2018. Published: May 15, 2018.

Copyright: (c) 2018 CSIC. This is an open-access article distributed under the terms of the Creative Commons Attribution 4.0 International (CC BY 4.0) License.

\section{INTRODUCTION}

The reform of the European Union Common Fisheries Policy brought into force the prohibition of discarding catches of regulated species (EC 2013). A Landing Obligation (LO) was included in this reform (Article 15 of EU Reg. 1380/2013) and affects all commercial species subject to catch limits or minimum landing sizes. In Mediterranean demersal fisheries, the LO is implemented in two phases: discards of species that define the fishery are prohibited from 1 January 2017 and the prohibition is extended to all other regulated species from 1 January 2019. The catches of regulated species below the minimum conservation reference size (MCRS) must be hauled and retained on board the fishing vessels, recorded and landed at ports; they may enter the productive economy for uses other than direct human consumption. Forcing producers to land former discards of regulated species is expected to be a significant step towards more selective fisheries (Prellezo et 
al. 2016). The total volume of discards (including nonregulated species) in EU Mediterranean trawl fisheries is estimated to range typically between $30 \%$ and $40 \%$ of the total catch (with extremes varying from $20 \%$ to $60 \%$ ) (Tsagarakis et al. 2014). However, the volume of discards of regulated species (Annex III of EU Regulation 1967/20016) is less well researched and it was estimated at less than $10 \%$, for instance, in a bottom trawl fishery of the Alicante area (SE Spain) (GarcíaRivera et al. 2015). Conversely, a recent study (Sartor et al. 2016) analysing Italian official fisheries data (EU Data Collection Framework, DCF) from 2009 to 2014 on the discards of the species characterizing the otter bottom trawl fisheries show that discards of European hake varied from $5 \%$ to $20 \%$ of the total catch, depending on the geographical subarea.

Geographical SubArea GSA06 ("Northern Spain”) is one of the 30 areas established by the General Fisheries Commission for the Mediterranean (GFCM) for fisheries stock assessment and management (http:// www.gfcm.org). Fisheries management of GSA06 stocks, as for other Mediterranean fish stocks except large pelagics, is based on input measures that control fishing effort by limiting the capacity of the fleet (licence scheme) and the activity of vessels (Lleonart and Maynou 2003). Fishing is not permitted on weekends and an obligatory daily return to base port (maximum 12 working hours per day) is enforced. There are MCRS for most target species, but they are not fully enforced, contributing to the low economic efficiency of fisheries exploitation, as elsewhere in the Mediterranean and the European Atlantic (Colloca et al. 2014, Macher and Boncoeur 2010). Bottom trawlers operate with fishing gear that has a legal minimum mesh size of $40 \mathrm{~mm}$ (square mesh). Because output management measures (i.e. total allowable catch or quotas) are not in place for Mediterranean fisheries, again with the exception of large pelagics, fisheries management does not strictly depend on annual stock assessments of the target species, as is the case in European Atlantic fisheries (Lleonart and Maynou 2003).

Demersal fisheries in GSA06 are carried out with a variety of fishing gear, although in terms of production otter bottom trawl is by far the most productive (Lleonart and Maynou 2003). Over two hundred species (or market categories) are routinely landed in fish markets by bottom trawlers, but the bulk of the catches and economic value is made up by only 25 species $(80 \%$ of value, Maynou 2014). Bottom trawlers in GSA06 practice two main fishing strategies: the mixed demersal fishery on the continental shelf and the deepwater fishery targeting valuable crustaceans.

Regardless of the LO, many studies point to the benefits of improving selectivity in trawl fisheries under biological and ecological criteria (Scott and Sampson 2011, Colloca et al. 2014, Maynou 2014). Selectivity improvements inevitably have short-term negative consequences for the fisheries operators' profitability, and consequently a low incentive for adoption, but will in the long term help rebuild stocks and produce higher yields, particularly in heavily overexploited resources such as Mediterranean stocks (Colloca et al.
2014). On the other hand, the analysis of the Basque trawl fishery in the Bay of Biscay by Prellezo et al. $(2016,2017)$ showed that private incentives can arise to improve the selectivity and reduce discards through the adoption of more selective fishing gear by fishers as a logical outcome of the LO, on bioeconomic grounds only. Naturally, any modifications to the current trawl design should be practical and inexpensive to facilitate its wide and fast adoption by fishers. Here we use mathematical simulation modelling to carry out a bioeconomic analysis of the effects of adopting the experimental net described in Sola and Maynou (2018), which has good selection properties for the two target species of the transition phase (2017-2018) of the discards ban.

\section{MATERIALS AND METHODS}

The most important species in the two fishing strategies practised in GSA06 by bottom trawlers, the continental shelf mixed demersal fishery and the deepwater crustacean fishery, are subject to regular stock assessments by the European Commission Scientific, Technical and Economic Committee for Fisheries (STECF)and the GFCM. Specifically, in recent years, the target species of the mixed demersal fishery (hake, red mullet, black anglerfish and blue whiting), as well as the three deepwater crustaceans (deepwater rose shrimp, Norway lobster and red shrimp) have been assessed by means of catch-at-age models from data submitted by national authorities to the STECF in the Data Collection Framework (STECF 2013, 2014, 2015a, 2015b, 2017). The biological parameters used in these assessments and their results (number at age, fishing mortality and biological reference points) were used to parameterize the bioeconomic model applied in this analysis (see below).

The economic parameters for the model were obtained from data sources such as the Annual Economic Report (STECF 2016) published by the STECF from official fisheries data (DCF) and national generic data available from https://stecf.jrc.ec.europa.eu/, complemented with our own observations in the MINOUW project (the H2020 Research and Innovation Action "Science, Technology and Society Initiative to Minimize Unwatched Catches in European Fisheries" (2015-2019), contract $n^{\circ}$ 634495). The economic parameters used were the average of the values for bottom trawlers in the 18-24 m and 24-40 m length classes because they are the most representative segments in terms of demersal fish production and comprise $75 \%$ of the bottom trawl fleet in GSA06.

\section{Simulation conditions and scenarios}

The model was projected for 15 years, with 2015 as year 0 and 1000 iterations in each scenario (Table 1). The results of the stochastic simulations were extracted as mean and $95 \%$ confidence interval for each indicator variable. For each of the seven demersal target species, the biological parameters in the corresponding stock assessments were used as baseline information (Table 
Table 1. - Definition of simulation scenarios for the bottom trawl fishery in GSA06 for the period 2015-2030, with technical intervention in 2017.

\begin{tabular}{|c|c|}
\hline Scenario 0 & Business as usual, no change in the projection conditions: standard trawl and unwanted catches discarded. \\
\hline Scenario 1 & Introduction of a modified bottom trawl design in 2017 (see Sola and Maynou, 2018); unwanted catches discarded. \\
\hline Scenario 2 & $\begin{array}{l}\text { As in Scenario 1, but with the existence of a market for unwanted catches paying } 0.20 € \mathrm{~kg}^{-1} \text {. The world market } \\
\text { value of fishmeal ranged between } 1400 \text { and } 2400 \mathrm{US} \$ \mathrm{t}^{-1} \text { in the period } 2012-2015 \text { (http://www.indexmundi.com/ } \\
\text { commodities/?commodity=fish-meal\&months }=60) ; \text { here we assume that fishmeal producers would pay a maximum } \\
\text { of } 1 / 10 \text { to fishers. Sartor et al. (2016) mention } 0.05 € \mathrm{~kg}^{-1} \text {. }\end{array}$ \\
\hline Scenario 3 & $\begin{array}{l}\text { As in Scenario 1, and no market for unwanted catches. Producers are obliged to meet the costs of disposal, at } 0.50 € \\
\mathrm{~kg}^{-1} \text { (Sartor et al. 2016). }\end{array}$ \\
\hline
\end{tabular}

Table 2. - Biological parameters used in the simulations, from stock assessments in STECF (2013, 2014, 2015a, 2015b, 2017).

\begin{tabular}{|c|c|c|c|c|c|}
\hline Stockname & Age & Number (000s) & mat & M & $\mathrm{F}$ \\
\hline M. merluccius & 0 & 100,806 & 0 & 1.240 & 0.119 \\
\hline M. merluccius & 1 & 26,126 & 0.15 & 0.580 & 1.227 \\
\hline M. merluccius & 2 & 2,788 & 0.82 & 0.450 & 1.605 \\
\hline M. merluccius & 3 & 225 & 0.98 & 0.400 & 1.340 \\
\hline M. merluccius & 4 & 30 & 1 & 0.370 & 0.282 \\
\hline M. merluccius & 5 & 4 & 1 & 0.350 & 0.282 \\
\hline L. budegassa & 0 & 11,817 & 0.09 & 1.080 & 0.010 \\
\hline L. budegassa & 1 & 4,387 & 0.14 & 0.480 & 0.380 \\
\hline L. budegassa & 2 & 2,481 & 0.21 & 0.370 & 1.630 \\
\hline L. budegassa & 3 & 295 & 0.3 & 0.320 & 1.340 \\
\hline L. budegassa & 4 & 50 & 0.41 & 0.290 & 0.290 \\
\hline L. budegassa & 5 & 24 & 0.54 & 0.270 & 1.320 \\
\hline L. budegassa & 6 & 10 & 0.66 & 0.260 & 7.050 \\
\hline L. budegassa & 7 & 0 & 0.91 & 0.250 & 2.940 \\
\hline L. budegassa & 8 & 0 & 1 & 0.240 & 2.940 \\
\hline$P$. longirostris & 0 & 109,502 & 0 & 1.250 & 0.000 \\
\hline P. longirostris & 1 & 27,656 & 0.13 & 0.820 & 0.110 \\
\hline P. longirostris & 2 & 11,657 & 0.5 & 0.390 & 0.933 \\
\hline P. longirostris & 3 & 2,779 & 0.79 & 0.280 & 1.523 \\
\hline P. longirostris & 4 & 396 & 0.9 & 0.240 & 2.007 \\
\hline P. longirostris & 5 & 44 & 0.97 & 0.220 & 1.494 \\
\hline P. longirostris & 6 & 3 & 1 & 0.210 & 1.494 \\
\hline M. barbatus & 0 & 93,000 & 0.46 & 0.990 & 0.118 \\
\hline M. barbatus & 1 & 29,100 & 0.76 & 0.460 & 2.220 \\
\hline M. barbatus & 2 & 2,050 & 0.88 & 0.300 & 2.082 \\
\hline M. barbatus & 3 & 103 & 0.93 & 0.240 & 1.665 \\
\hline M. barbatus & 4 & 50 & 1 & 0.210 & 1.665 \\
\hline A. antennatus & 0 & 279,420 & 0.08 & 1.250 & 0.001 \\
\hline A. antennatus & 1 & 72,120 & 0.77 & 0.580 & 0.608 \\
\hline A. antennatus & 2 & 15,798 & 1 & 0.440 & 0.274 \\
\hline A. antennatus & 3 & 2,291 & 1 & 0.390 & 0.689 \\
\hline A. antennatus & 4 & 609 & 1 & 0.350 & 0.267 \\
\hline A. antennatus & 5 & 200 & 1 & 0.310 & 0.267 \\
\hline N. norvegicus & 1 & 34,479 & 0.05 & 0.470 & 0.010 \\
\hline N. norvegicus & 2 & 31,867 & 0.14 & 0.370 & 0.316 \\
\hline N. norvegicus & 3 & 16,107 & 0.32 & 0.290 & 0.780 \\
\hline N. norvegicus & 4 & 4,264 & 0.58 & 0.260 & 0.732 \\
\hline N. norvegicus & 5 & 1,289 & 0.8 & 0.240 & 0.647 \\
\hline N. norvegicus & 6 & 448 & 0.92 & 0.230 & 0.480 \\
\hline N. norvegicus & 7 & 105 & 0.97 & 0.220 & 0.438 \\
\hline M. poutassou & 0 & 103,067 & 0 & 1.180 & 0.019 \\
\hline M. poutassou & 1 & 34,144 & 0.01 & 0.530 & 1.113 \\
\hline M. poutassou & 2 & 3,709 & 0.61 & 0.390 & 2.387 \\
\hline M. poutassou & 3 & 253 & 1 & 0.340 & 1.508 \\
\hline M. poutassou & 4 & 25 & 1 & 0.310 & 1.969 \\
\hline M. poutassou & 5 & 3 & 1 & 0.290 & 1.969 \\
\hline
\end{tabular}

2) (STECF 2013, 2014, 2015a, 2015b, 2017). For most stocks, the last year of assessment was 2014 (which is used here as the last observed year), though for deepwater rose shrimp the series terminated in 2013 and was projected until 2014.

The objective of this work was to assess the effect of the discards ban in the transition period 2017-2018 when only two species, viz. hake and red mullet, fall under the discards ban. The MCRSs are 20 and $11 \mathrm{~cm}$ total length for hake and red mullet, respectively. We used the results of Sola and Maynou (2018) to simulate the adoption of a modified bottom trawl design using a T90 extension net to reduce the catches of undersize hake and red mullet. In all cases, effort was kept constant at the level estimated for bottom trawlers in 2014, and given as 68700 days-at-sea (DAS).

\section{Model description}

The bioeconomic model used was the same as the one described in Maynou (2014), with the addition of a module describing the production of unwanted catches 
and a market for former discards. The biological model contains a standard age-structured fish population dynamics model (Shepherd and Pope 2002), and the economic model is based on the accounting of economic units (here, the bottom trawl fleet in GSA06). The link between the biological and the economic models is fishing mortality, made proportional to fishing effort.

The dynamics of the number of individuals by age class $a$ of the seven main species $i$ at time $t+1$ are modelled as:

$$
\begin{gathered}
N_{i, a, t+1}=N_{i, a-1, t} e^{\left(-M_{i, a-1}-F_{i, a-1}\right)}, a=2, \ldots, A_{i}-1 \\
N_{i, A_{i}, t+1}=N_{i, A_{i}-1, t} e^{\left(-M_{i, A_{i}-1}-F_{i, A_{i}-1}\right)}+N_{i, A_{i}, t} e^{\left(-M_{i, A_{i}}-F_{i, A_{i}}\right)}
\end{gathered}
$$

where $N_{i, a, t}$ is the abundance at the beginning of year $t$ for each species and age class, and $M_{i, a}$ and $F_{i, a}$ are the vectors of natural mortality and fishing mortality, respectively. In this model application, recruitment was considered stochastic around a constant mean value (a geometric mean of the three most recent years), given the difficulties of establishing the parameters of spawning stock-recruitment $(S S B / R)$ models for Mediterranean fish stocks:

$$
N_{i, 0, t}=R_{i} * \exp \left(\varepsilon_{i}\right)
$$

where $R_{i}$ is recruitment and $\varepsilon_{i}$ is a normally distributed random variable with mean 0 and standard deviation equal to the standard deviation of the recruitment series observed in the periods covered by the assessments (STECF 2013, 2014, 2015a, 2015b, 2017).

The natural mortality vector was considered constant throughout the simulation horizon. The fishing mortality vector was kept constant at the values produced by the stock assessments in Scenario 0 , but a new $F$ was recalculated in Scenarios 1-3 for hake and red mullet to account for the escape of individuals through the modified trawl:

$$
F_{i, a}=p_{i, a} F_{i, a, 0}
$$

where $p_{i, a}$ is the fraction retained by the modified trawl (Sola and Maynou 2018) per age class. The parameter $p_{i, a}$ was derived from the catch ratio in length by these authors and using the length-to-age conversion model of Hordyk et al. (2014, see below).

The mean annual biomass of the population $\left(\bar{B}_{i, a}\right)$ of each species by age class was computed with

$$
\bar{B}_{i, a}=\bar{N}_{i, a} w_{i, a}
$$

where $\left(\bar{N}_{i, a}\right)$ is the mean number at age and $w_{i, a}$ is the mean weight at age; and integrating for all age classes,

$$
\bar{B}_{i}=\sum_{a=1}^{A_{i}} \bar{B}_{i, a}
$$

The spawning stock biomass for each species was projected with the formula

$$
S S B_{i, t}=\sum_{a=1}^{A_{i}} S S B_{i, a, t}=\sum_{a=1}^{A_{i}} I_{i, a} \bar{B}_{i, a, t}
$$

Table 3. - Average ex-vessel sale price for the target stocks of the bottom trawl fleet (average for the period 2012-2014).

\begin{tabular}{lc}
\hline \multicolumn{1}{c}{ Species } & Ex-vessel price $\left(€ \mathrm{~kg}^{-1}\right)$ \\
\hline Merluccius merluccius & 6.80 \\
Lophius budegassa & 7.80 \\
Parapenaeus longirostris & 9.90 \\
Mullus barbatus & 5.00 \\
Aristaeus antennatus & 29.80 \\
Nephorps norvegicus & 18.90 \\
Micromesistius poutassou & 3.10 \\
\hline
\end{tabular}

where $I_{i, a}$ is a vector of maturity proportion by age class and species.

The catches by species were produced with the classical Baranov catch equation (Baranov 1918) and converted to weight:

$$
C_{i, t}=\sum_{a=1}^{A_{i}} N_{i, a, t}\left(1-e^{-\left(M_{i, a}+F_{i, a, t}\right)}\right) w_{i, a} \frac{F_{i, a, t}}{M_{i, a}+F_{i, a, t}}
$$

The combined catches of the main species are

$$
C_{t}=\sum_{i} C_{i, t}
$$

In the economic submodel, the catches of the seven main species are complemented by catches of other commercial species whose population dynamics are not explicitly modelled to produce the total fishery yield $\left(Y_{\mathrm{t}}\right)$. The income for the fleet results from the product of landings of the target species in addition to landings of commercial by-catch species, modelled here as a proportion $\delta$ of the target species landings. For the GSA06 trawl fleet, official fisheries landings statistics (DCF) were used to estimate that the volume of commercial by catch is $\delta=2.4$ times the volume of the target species. The average prices in 2014 of target species $\left(p_{i}\right)$ (Table 3$)$ and commercial by-catch $\left(p_{s}\right.$, estimated at $5.80 € \mathrm{~kg}^{-1}$ ) were estimated for the fleet from the same sources and were assumed constant throughout the simulations. The landings income of the fleet is therefore

$$
Y_{t}=\sum_{i} C_{i, t} p_{i}+\left(\sum_{i} C_{i, t}\right) \delta p_{s}
$$

Gross profit $\pi$ of the fleet was computed from the difference between income and costs (Table 4):

$$
\pi_{t}=\left(Y_{t}-\tau Y_{t}-C C \cdot e_{t}\right) \gamma-(C V F+K \sigma) e_{t}
$$

where $\tau$ is the commercial cost coefficient, $C C$ are coefficients of common effort costs (mainly, energy costs), $\gamma$ is the share coefficient (the part to the owner), CVF are variable and fixed effort costs per unit effort, $K$ is the capital of one unit effort (estimated from the sale value of the vessels), and $\sigma$ is the depreciation rate of one unit of capital. Capital depreciation costs were assumed to be $10 \%$ of the value of capital.

The labour costs are given by the following expression:

$$
L_{t}=\left(Y_{t}-\tau Y_{t}-C C \cdot e_{t}\right)(1-\gamma)
$$

The gross profits were computed without subsidies because it is uncertain whether direct subsidies to the 
Table 4. - Types of costs considered in the model. Common costs (commercial costs and energy costs) are deducted from the landings revenue before deducting crew wages, as practised in share remuneration systems.

\begin{tabular}{|c|c|c|}
\hline Cost 1 & $\begin{array}{l}\text { Commercial costs as a function of total revenues (com- } \\
\text { mon costs). }\end{array}$ & $\tau=19 \%$, including sales tax, harbour dues, crates and boxes. \\
\hline Cost 2 & $\begin{array}{l}\text { Costs related to fishing effort, mainly fuel or energy } \\
\text { costs (common costs). }\end{array}$ & $\begin{array}{l}C C=1185.5 € / \mathrm{DAS} / \text { vessel, which comprises mainly fuel } \\
\text { costs and other minor running costs such as lubricants and } \\
\text { crew food. }\end{array}$ \\
\hline Cost 3 & $\begin{array}{l}\text { Labour costs, following the share system, where com- } \\
\text { mon costs are deducted from the total revenue and split } \\
\text { between the owner and the crew. }\end{array}$ & $\begin{array}{l}\gamma=50 \% \text { to the owner; additionally, an average salary for the } \\
\text { crew (AL) was computed, assuming a crew of four in each } \\
\text { vessel. }\end{array}$ \\
\hline Cost 4 & $\begin{array}{l}\text { Variable costs, including engine repair and vessel main- } \\
\text { tenance, and fixed costs, including licence and mooring } \\
\text { fees. }\end{array}$ & $\mathrm{CVF}=113.48 € / \mathrm{DAS}$ \\
\hline
\end{tabular}

fishery will be available from 2017. However, the subsidies received annually by the trawl fleet in GSA 06 are estimated at approximately $3 \%$ of the value of landings in STECF (2016).

\section{Discards}

Estimations of discards are available from official sources (DCF) for the period 2011-2014 for some of the species considered here, although these estimates should be considered as minimum values only. Typically, the estimates produced in the reports (STECF 2013, 2014, 2015a, 2015b, 2017) range between 0\% and $10 \%$ of the total catch in volume, depending on the species.

An age-length transition matrix (Hordyk et al. 2014) was built from the mean length at age and variance of length at age calculated from the size frequencies for hake and red mullet in the official data source, combining size-frequency histograms of the years 2013-2014.

The probability of individuals of age a being in length class $i$ is

$$
P_{l, a}=\left\{\begin{array}{cc}
\varphi\left(\frac{X_{l+1}^{l_{0}}-X_{a}}{\sigma_{X_{a}}}\right) & l=1 \\
\varphi\left(\frac{X_{l+1}^{l_{0}}-X_{a}}{\sigma_{X_{a}}}\right)-\varphi\left(\frac{X_{l}^{l_{0}}-X_{a}}{\sigma_{X_{a}}}\right) & 1<l<L \\
1-\varphi\left(\frac{X_{l}^{l_{0}}-X_{a}}{\sigma_{X_{a}}}\right) & l=L
\end{array}\right.
$$

where $\varphi$ is the standard normal cumulative distribution function, is the upper bound of length class 1 , and $\mathrm{L}$ is the total number of length classes. $X_{a}$ and $\sigma_{X a}$ are the mean and the standard deviation of the normal component of age class a. The age-length probability matrix was modified for the experimental fishing gear by multiplying by the expected catch ratio from Sola and Maynou (2018):

$$
p_{l, a}=P_{l, a} C R_{l}
$$

where $C R_{l}$ is the catch ratio by length class $l$.

The mean length-at-age $X_{a}$ and its variance $\sigma_{X a}{ }^{2}$ were computed with the R version of the MIX model (library mixdist v. 0.5-4 in R v. 3.0.2: http://www.math.mcmas- ter.ca/peter/mix/mix.html; Macdonald and Green 1988). The mix algorithms assume that a size-frequency histogram is the addition of $n$ Gaussian distributions with mean $\mu$ and standard deviation $\sigma$. We used the default algorithm in the mix function of the mixdist library, with starting values compatible with the von Bertalanffy parameters used in the stock assessments of hake and red mullet (STECF 2015a).

The ogive of unwanted catches by age was computed for hake and red mullet by adding the proportions in the age-length probability matrix in each age class:

$$
U W C_{a}=\sum_{l=1}^{L} p_{l, a}
$$

In the present work, we will consider perfect compliance with the LO in Scenarios 2 and 3, i.e. all undersize catches are either sold to processing markets or destroyed, at a cost to the producer.

\section{RESULTS}

The size frequency of bottom trawl catches in GSA06 for hake and red mullet are shown in Figure 1 , with the modal distribution of age classes as established by the MIX model (Table 5). Only three age classes for hake and two for red mullet can be statistically detected from these data. For our purposes, this is sufficient because the first classes are the ones that produce unwanted catches under MCRS. For age class 0 , the retention ogive of the modified net configuration was estimated at practically 0 (Table 5), while retention for ages 2 were practically 1.0 for both species.

The projections of the biological indicators for each species, under the assumption of stochastic mean recruitment, are shown in Figures 2 and 3. In the control scenario, with no modification in the trawl net, the average fishing mortality of the last three years is as-

Table 5. - Parameters of the normal distribution functions whose mixture described the histograms of the landings length-frequency data for hake and red mullet, based on the mix model estimates (Fig. 1). Right column ogive for unwanted catches converted to ages in the modified trawl net $\left(U W C_{\mathrm{a}}\right) . X_{a}$, mean length (cm TL) of the mode; $s_{a}$, standard deviation; $P_{l, a}$, proportion of the histogram.

\begin{tabular}{lcc}
\hline & $X_{a}-s_{a}-P_{l, a}$ & $U W C_{\mathrm{a}}$ \\
\hline Hake, age class 0 & $14.09-2.33-0.332$ & 0.001 \\
Hake, age class 1 & $23.20-3.84-0.449$ & 0.065 \\
Hake, age class 2 & $32.94-5.45-0.219$ & 0.998 \\
Red mullet, age class 0 & $13.38-1.92-0.266$ & 0.001 \\
Red mullet, age class 1 & $16.99-2.44-0.734$ & 0.250 \\
\hline
\end{tabular}



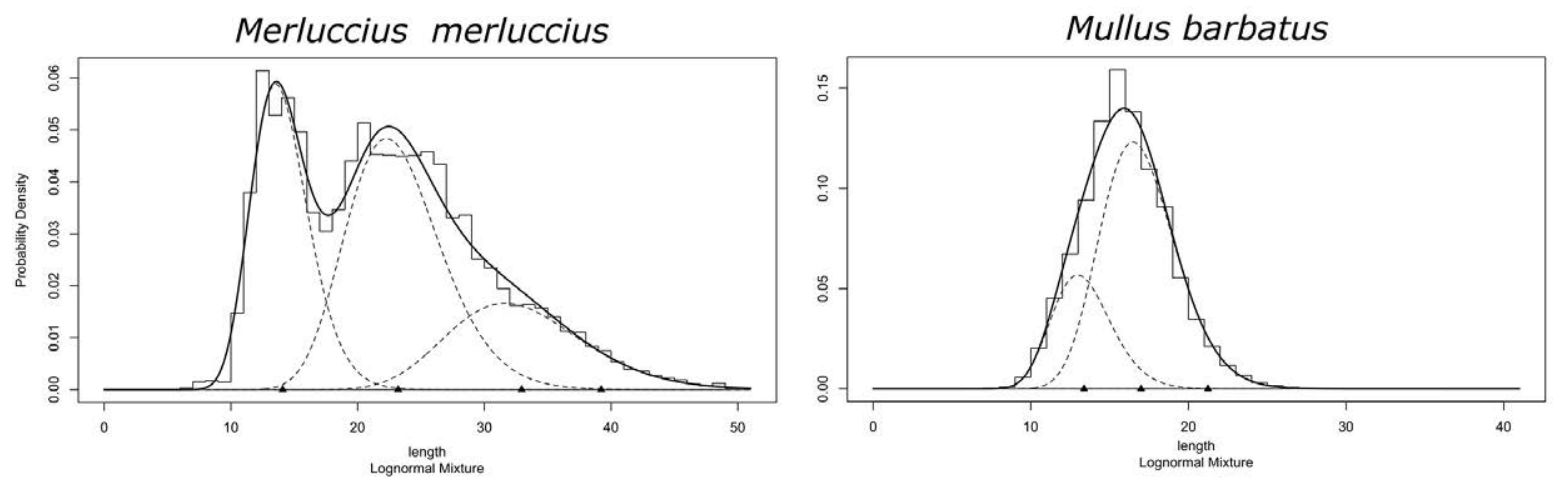

Fig. 1. - Histograms of landings length-frequency data (EC fisheries Data Collection Framework) for hake (left) and red mullet (right) with normal distribution functions estimated for age classes (dashed lines) and distribution function mixture (overall continuous line).

\section{Merluccius merluccius}
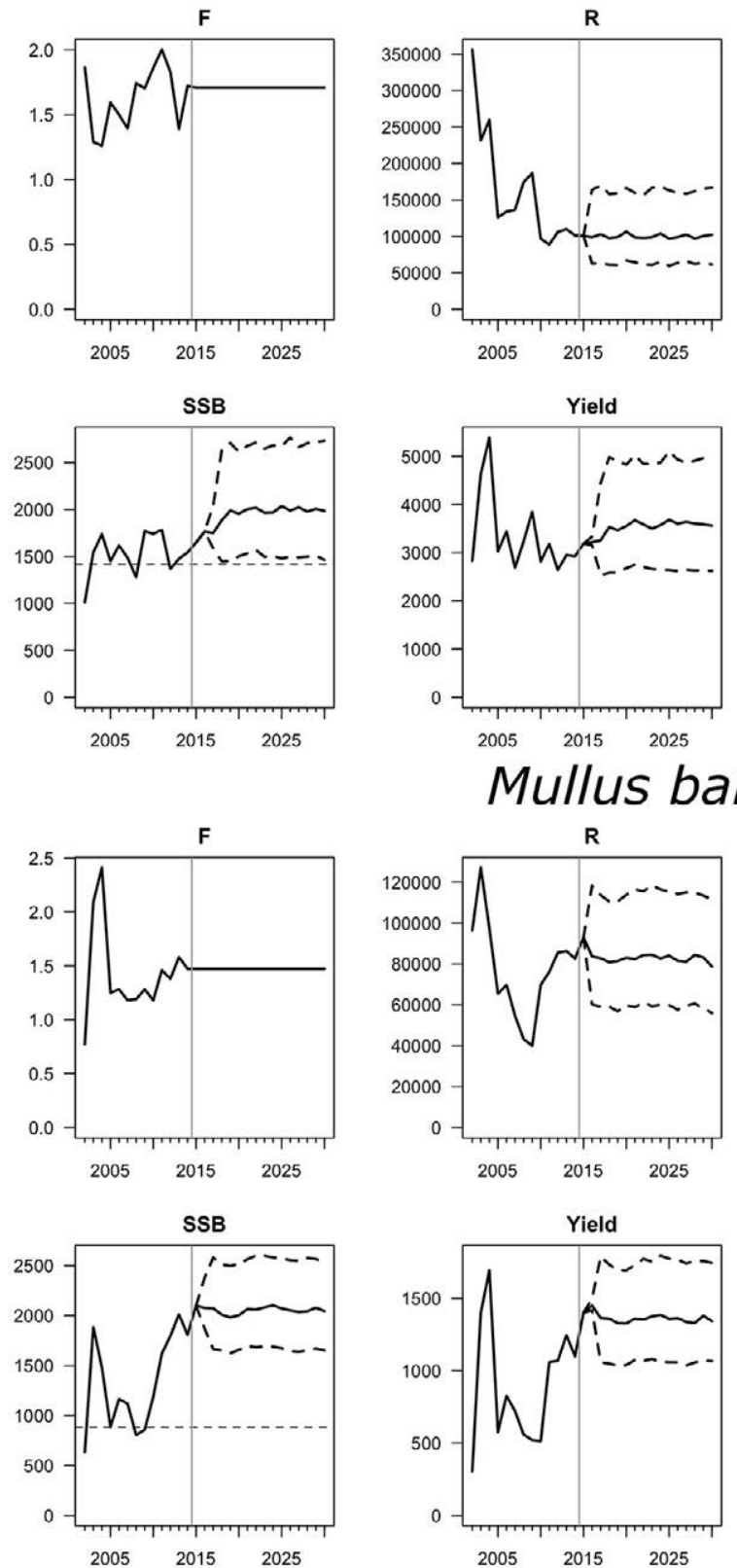

Mullus barbatus
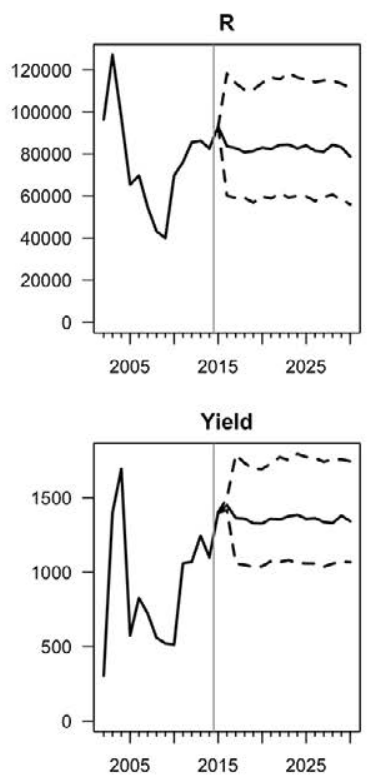

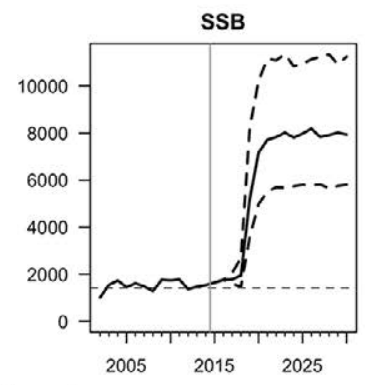

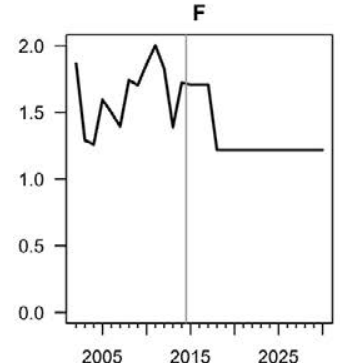
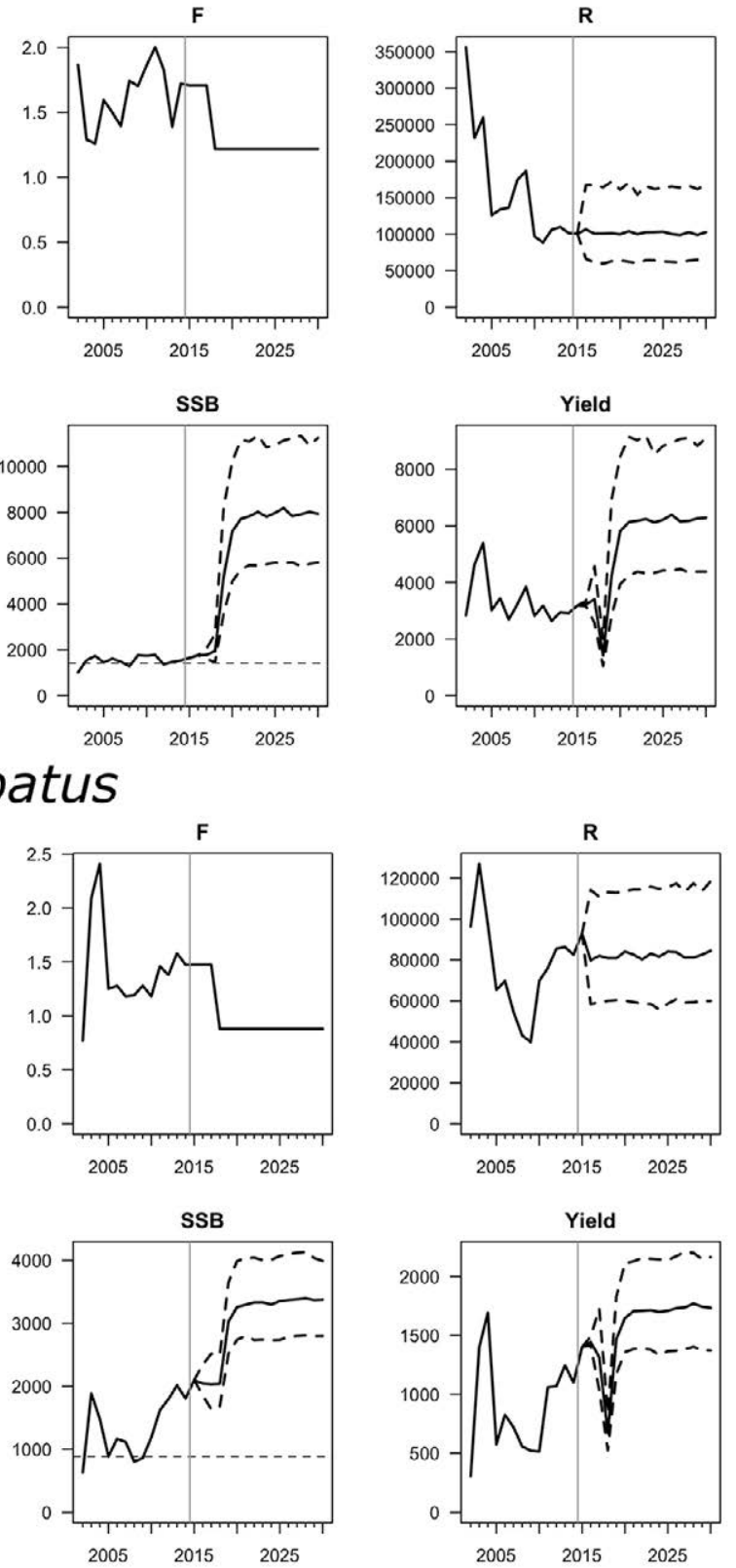

Fig. 2. - Results of the simulations (biological indicators) for the two species under the discards ban in the period $2017-2018$ (mean and 95\% CI). Left panels: Scenario 0 with no intervention. Right panels: introduction of a modified bottom trawl net favouring the escape of undersize individuals in 2017. Horizontal dotted line in the spawning stock biomass indicator is the reference point $S S B_{\text {lim }}$, computed as $S S B_{\text {lim }}=1.4 * S S B_{\text {min }}$, where $S S B_{\min }$ is the minimum value of $S S B$ observed in the historical data series. 
Aristeus antennatus
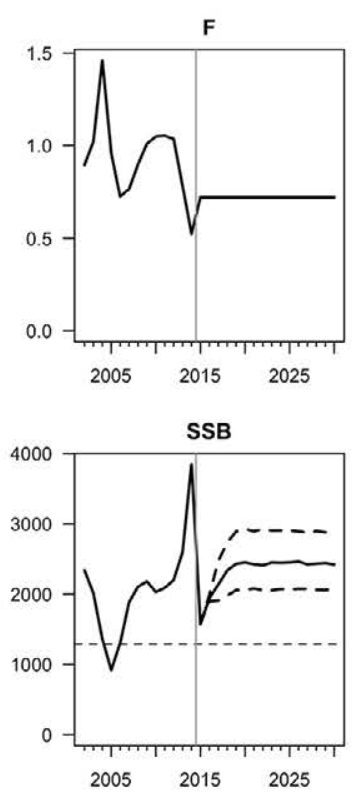

R
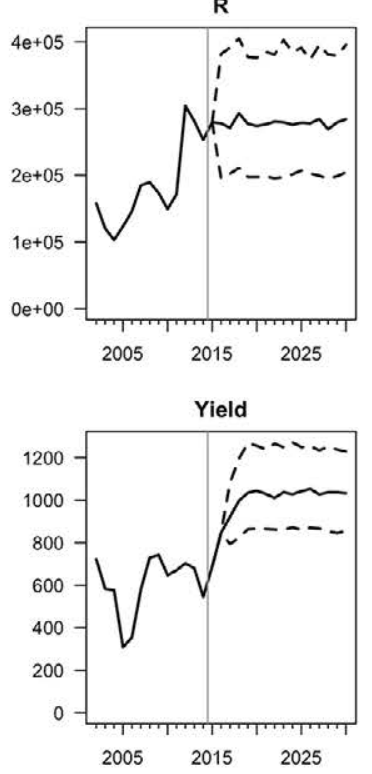

Parapenaeus longirostris
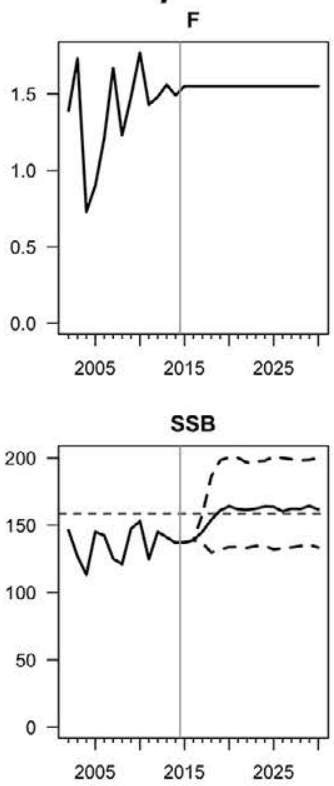
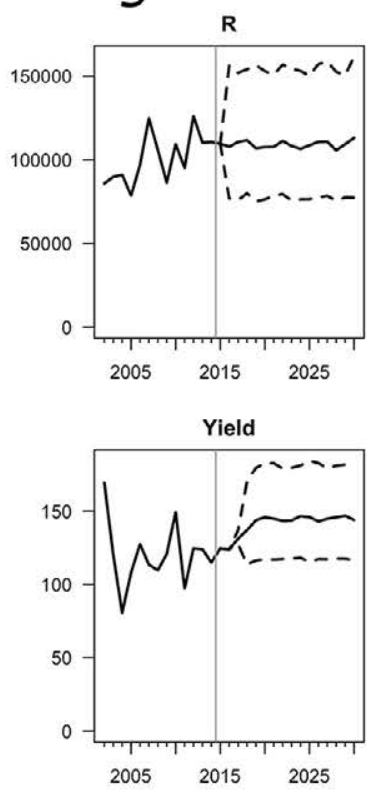

Nephrops norvegicus
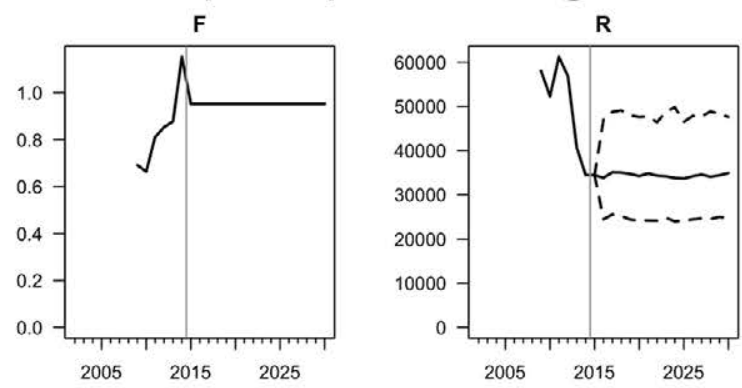

Lophius budegassa
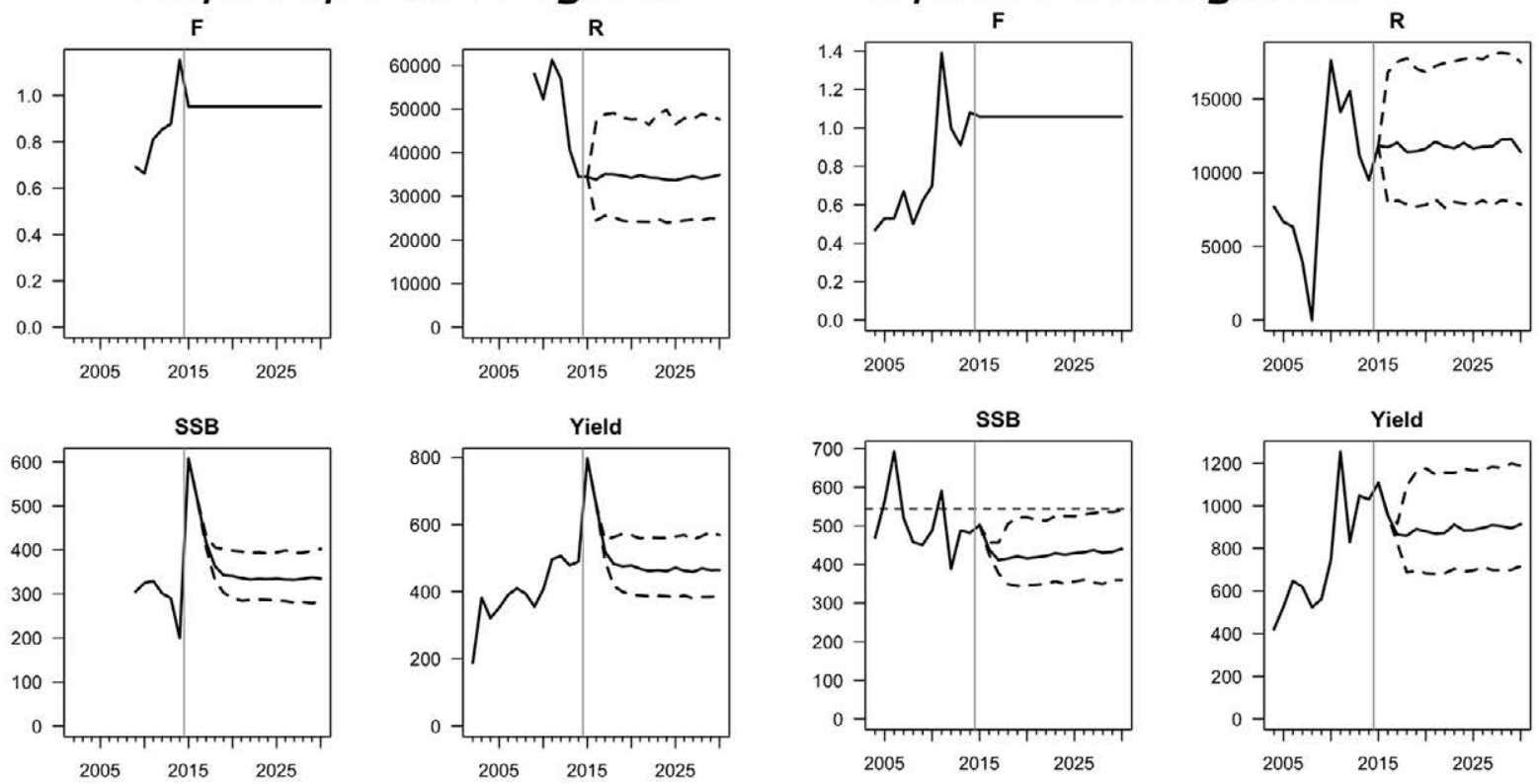

\section{Micromesistius poutassou}
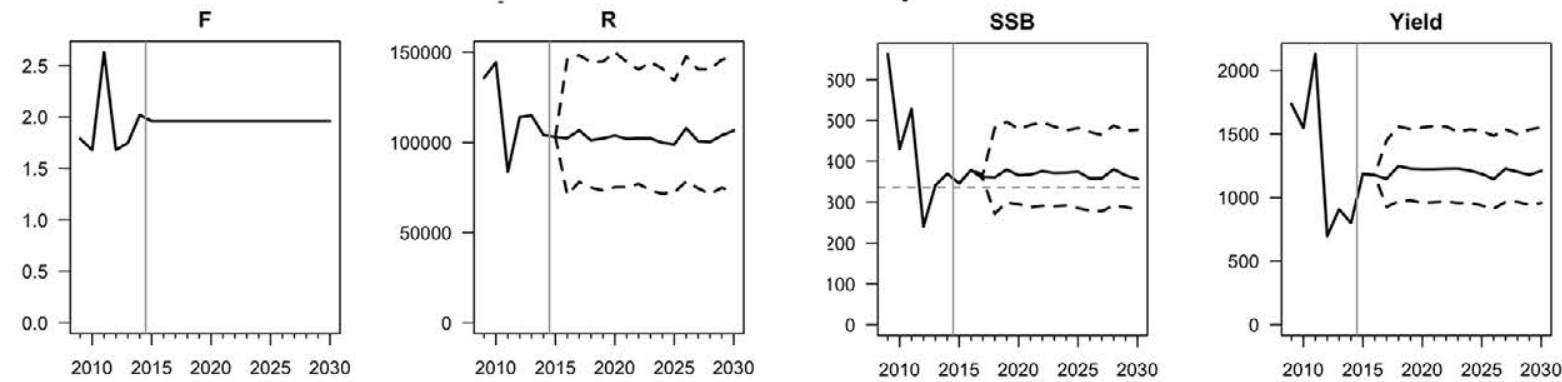

Fig. 3. - Results of the simulations (biological indicators) for the other species not under the discards ban in the period 2017-2018, for which no effect of the introduction of the new bottom trawl design is simulated (mean and 95\% CI). Note that the projections are all similar under the four scenarios for these species. 

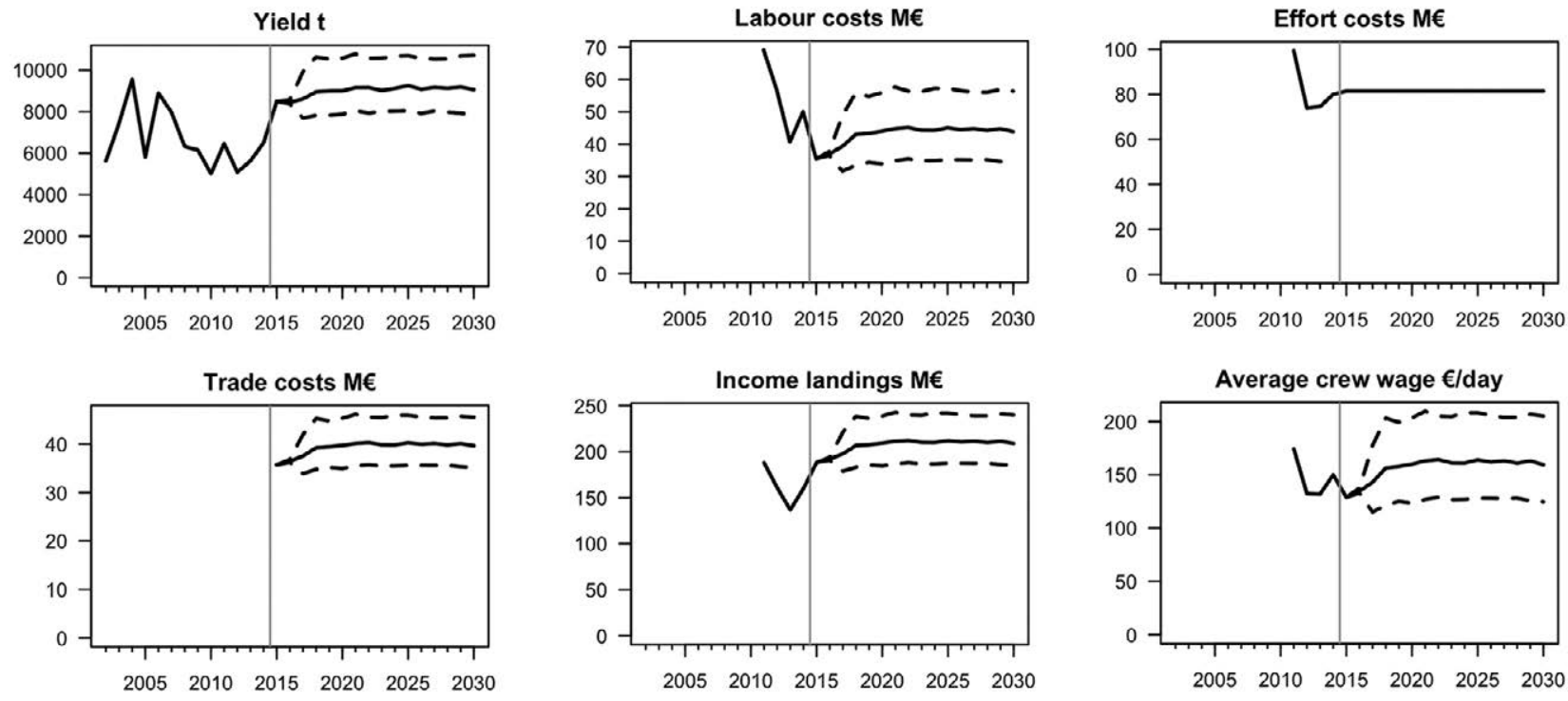

Fig. 4. - Evolution of economic indicators under Scenario 0 (mean and 95\% CI). The grey vertical line shows the start of the simulated data (2015); to its left are observed data.
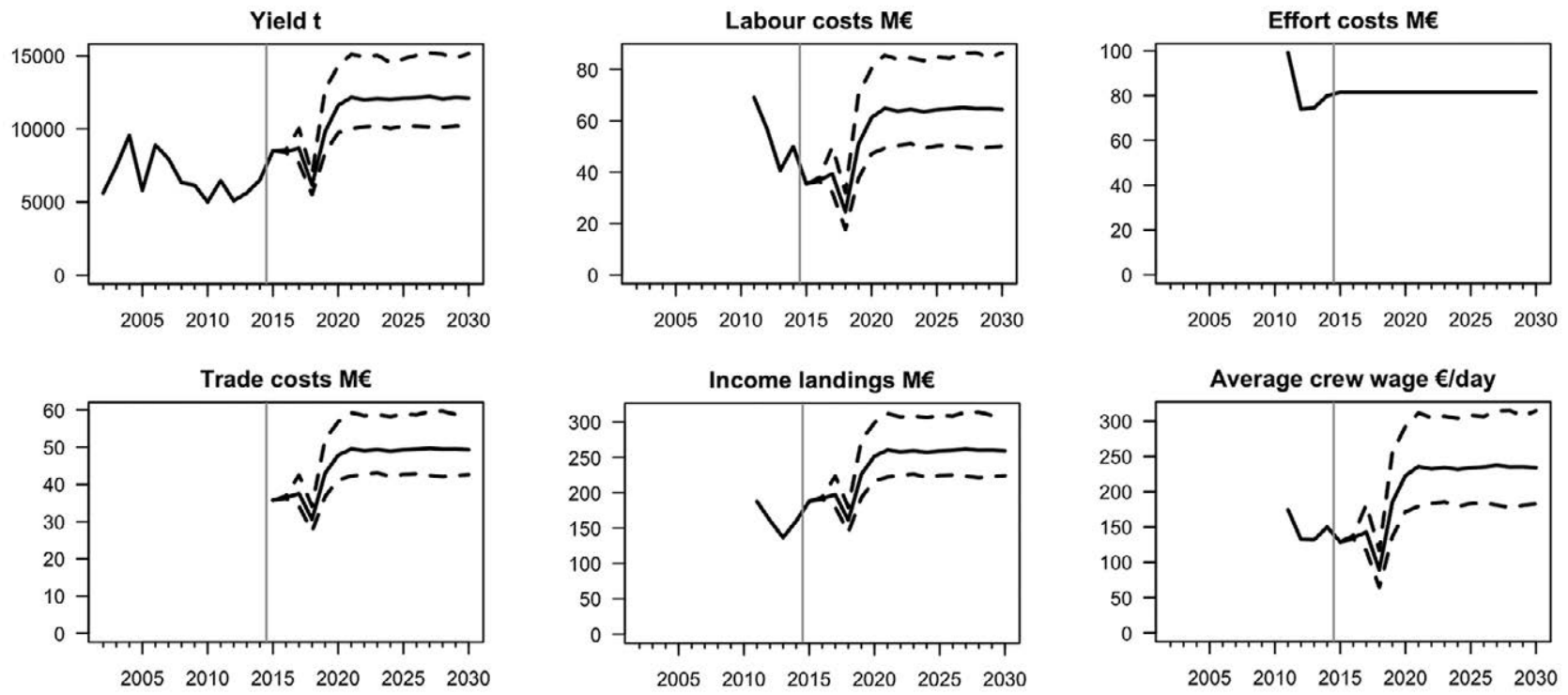

Fig. 5. - Evolution of economic indicators under Scenario 1 (mean and 95\% CI), with the introduction of the modified trawl net in 2017. Note that the results for Scenarios 2 and 3 are practically indistinguishable. The grey vertical line shows the start of the simulated data (2015); to its left are observed data.

sumed to continue over the simulation horizon. Given the relatively high stock status estimated for most species in recent years (as shown here by the SSB indicator), catches are expected to be around the mean values observed in the years of the historical data series or higher. The introduction of a modification to the trawl net simulated from 2017 onwards providing better escape for juvenile hake and red mullet would involve a reduction in the fishing mortality of age class 0 in both species, and is projected to result in a rapid increase in spawning stock biomass (Fig. 2, right panel) and shortterm catch losses for both species. However, the catch losses are not expected to last more than one year, given the rapid rebuilding of biomass. In economic terms, a comparison of Figures 4 and 5 shows a corresponding short-term reduction in the income from landings (and an associated reduction in other indicators, such as trade costs, labour costs and average crew wage), but income from landings was projected to reach higher values due to the increase in landings from hake and red mullet after 2018 (Fig. 5).

The amount of discards projected for 2015 and 2016, about $900 \mathrm{t}$ for hake and red mullet combined,

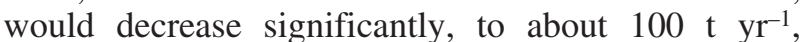
from 2017 onwards after the introduction of the trawl modification (Fig. 6). The value of former discards, in case of non-commercial use, would produce losses of $c a$. $€ 0.5$ million before the adoption of the new net. However, these losses would decrease rapidly by $90 \%$ with the adoption of the new net from 2017 onwards (Fig. 7). Likewise, if former discards were used commercially, the revenues from this source would amount 


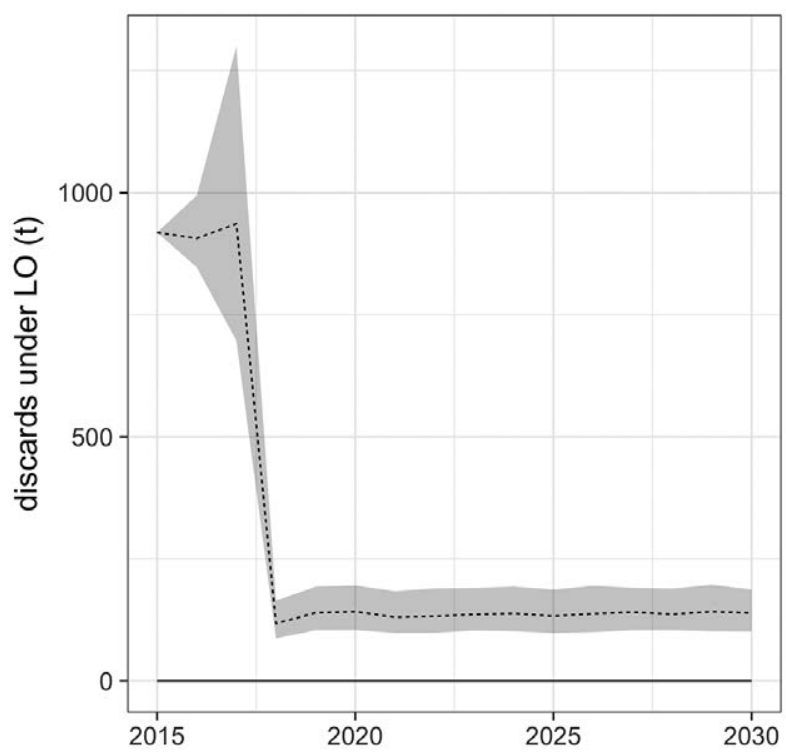

Fig. 6. - Volume of combined unwanted catches of hake (Merluccius merluccius) and red mullet (Mullus barbatus) under the remit of the Landings Obligation (LO) from 2017.

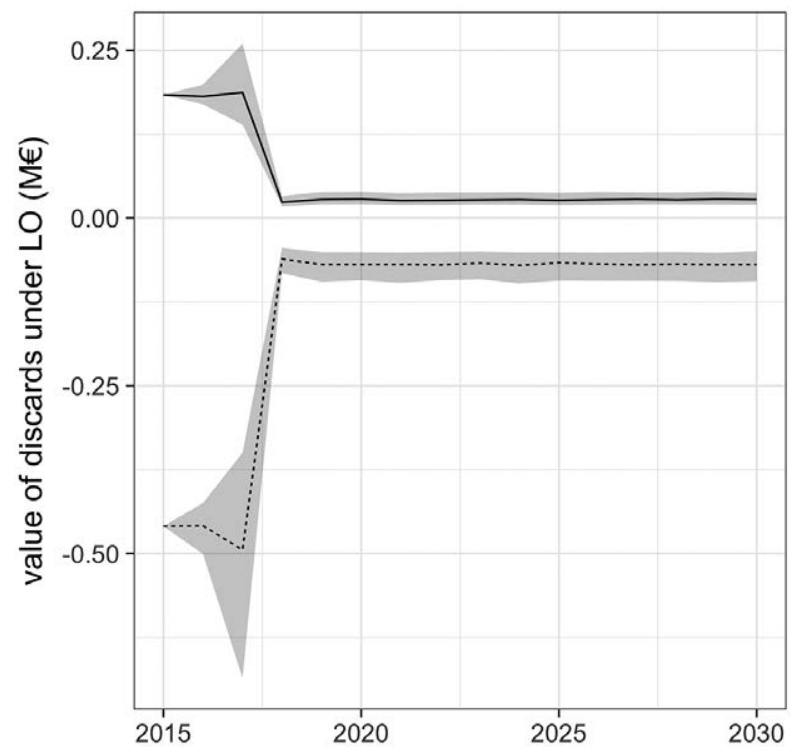

Fig. 7. - Income from unwanted catches of hake (Merluccius merluccius) and red mullet (Mullus barbatus) under the remit of the Landings Obligation (LO) from 2017. If former discards can be marketed for uses other than human consumption, positive values are expected (continuous black line), while if producers are required to dispose of former discards because of lack of market interest, negative values are expected (dotted line).

to $€ 0.2$ million before the adoption of the new net and ca. €0.02 million after 2017 (Fig. 7). In both cases, the amount of income or loss from unwanted catches of hake and red mullet is estimated at less than $€ 1$ million or less than $0.5 \%$ of the income generated by the bottom trawl fishery (Figs 4 and 5, top right panel).

\section{DISCUSSION}

Our results show that the volume of unwanted catches under the MCRS for hake and red mullet (un- der the remit of the LO from the beginning of 2017) is relatively low in terms of overall bottom trawl fisheries production. Their obligatory landing and sale for nonhuman consumption would produce small additional revenue to trawler operators, of the order of $€ 0.2$ million assuming a relatively high price of $0.20 € \mathrm{~kg}^{-1}$ for this product paid by fishmeal producers, for example. Adding the production of former discards from other demersal species that will produce unwanted catches from 2019, with the full implementation of the LO, is unlikely to double the additional revenue from former discards to trawl operators. In our analysis we have ignored the additional handling costs of former discards brought to land, but from personal interviews with producers (Maynou et al. 2018), these are not expected to be disproportionate. Our model does not include any investments by fishers that would be necessary to comply with the LO, but these are expected to be low. If former discards cannot be utilized industrially due to the lack of market, and producers are obliged to destroy the product at an estimated $0.50 €$ $\mathrm{kg}^{-1}$ (Sartor et al. 2016), a minimum loss of income of $€ 0.5$ million can be expected. This figure does not include additional costs of disposal for 2019 and later or handling costs. Considering the magnitude of the income of bottom trawl fisheries in GSA06 ( $\mathrm{ca}$. €200 million), the introduction of the LO without technical adaption of the fishing gear is not expected to produce significant losses of revenues to operators. Modifying trawl nets to allow the escape of the undersize fraction of regulated species would yield important losses in profits in the short term (Table 6, Scenarios 1-3 for 2018), but the expected recovery of the stocks would quickly offset this loss. It is important to note that even if the amount of catches below the MCRS of hake is relatively low in terms of weight (typically $5 \%-10 \%$ of catch), the amount of catches in number of individuals is very high (30\% or more: Fig. 1). In our model, the simulated increased escape of individuals below $20 \mathrm{~cm}$ total length with the adoption of the trawl modification described in Sola and Maynou (2018) significantly decreases fishing mortality (from Fbar $_{1-3}=1.71$ in 2015 to Fbar $_{1-3}=1.22$ in 2017) and helps explain the rapid rebuilding of the stock under constant recruitment conditions.

All in all, the adoption of more selective fishing gear is expected to help rebuild stocks and increase the profitability of bottom trawl fisheries, regardless of the commercial fate of unwanted catches under the remit of the LO. Our scenarios provide only minimum estimates because the adoption of a more selective trawl design, such as the one described in Sola and Maynou

Table 6. - Gross profits (landings income-costs, €M) in the simulation scenarios (Table 1) for the bottom trawl fleet in GSA06 at the beginning of the simulation (2015), one year after the introduction of the new trawl net (2018), and in 2020.

\begin{tabular}{ccccc}
\hline year & Scenario 0 & Scenario 1 & Scenario 2 & Scenario 3 \\
\hline 2015 & \multicolumn{4}{c}{6.599} \\
2018 & 14.115 & -4.332 & -5.414 & -5.086 \\
& $(4.568-26.956)$ & $(-11.207-3.153)$ & $(-11.822-3.373)$ & $(-11.498-3.246)$ \\
2020 & 15.120 & 32.396 & 31.726 & 32.281 \\
& $(5.036-27.060)$ & $(18.306-51.525)$ & $(18.671-49.902)$ & $(18.725-50.997)$ \\
\hline
\end{tabular}


(2018), will certainly increase escape and probably decrease fishing mortality of juvenile fish of other species in this mixed bottom-trawl fishery. The scenarios analysed work with the $F$ given by the change in fishing gear, disregarding other factors resulting from effort control or optimization of the means of production (labour, capacity).

Colloca et al. (2014) recommended changes in the selectivity patterns to decrease fishing mortality and delay the age at first capture as a more practical and efficient way to recover Mediterranean fish stocks than mere effort-reduction measures. Additionally, in light of the current Common Fisheries Policy, in which a ban of discards on regulated species can provide additional incentives for improving fisheries selectivity (Prellezo et al. 2016, 2017), our results show that it is possible to reduce fishing mortality and contribute to stock rebuilding by relatively simple, inexpensive modifications to trawl nets that enhance size selectivity.

The adoption of simple but efficient technological changes to bottom trawls can be a positive step towards reducing catches of the unwanted fraction of regulated species. In the short term, the introduction of the new fishing gear would have negative economic consequences, which are unlikely to last more than one or two years given the rapid turnover rates of Mediterranean fish stocks. The real impact in the medium to long term is harder to forecast for two main reasons: First, the strong stock rebuilding predicted by simple biological models under constant recruitment assumptions may be far from the reality of dynamic ecosystems with complex relationships among the components (e.g. intra-specific density dependence and inter-species interactions). Heath et al. (2014), based on a complex ecosystem model, showed how a discards ban in the North sea, without accompanying fisheries management measures, would even have adverse consequences on seabirds and other taxa that depend on discards for breeding success. Second, the extent to which the discards ban will be truly enforced in Mediterranean fisheries is uncertain. At current market prices, undersize fish have a much higher commercial value for human consumption than their value for purposes other than human consumption, such as reduction to fishmeal. As short-term economic incentives are lacking, the implementation of the LO will rely to a great extent on persuading the industry that stock rebuilding will produce future higher yields, or on strongly disincentivizing non-compliance.

\section{ACKNOWLEDGEMENTS}

This study received funding from the European Commission's Horizon 2020 Research and Innovation Programme under Grant Agreement No. 634495 for the project "Science, Technology, and Society Initiative to Minimize Unwanted Catches in European Fisheries" (MINOUW). The authors thank the European Commission (DG MARE and the Joint Research Centre) for facilitating access to the fisheries Data Collection Framework database.

\section{REFERENCES}

Baranov F.I. 1918. On the question of the biological basis of fisheries. Nauchnyi- Issledovatelskii Ikhtiologicheskii Institut, Izvestiya, 1: 81-128 (in Russian).

Colloca F., Cardinale M., Maynou F., et al. 2014. Rebuilding Mediterranean fisheries: a new paradigm for ecological sustainability. Fish Fish. 14: 89-109. https://doi.org/10.1111/j.1467-2979.2011.00453.x

European Commission (EC). 2013. European Council Regulation No 1380/2013 of the European Parliament and of the Council of 11 December 2013 on the Common Fisheries Policy, amending Council Regulations EC No 1954/2003 and EC No 1224/2009 and repealing Council Regulations EC No 2371/2002 and EC No 639/2004 and Council Decision 2004/585/EC. Official Journal of the European Union, L 354.

García-Rivera S., Sánchez Lizaso J.L., Bellido Millán J.M. 2015. A quantitative and qualitative assessment of the discard ban in European Mediterranean waters. Mar. Pol. 53: 149-158. https://doi.org/10.1016/j.marpol.2014.12.003

Heath M.R., Cook R.M., Cameron A.I., et al. 2014. Cascading ecological effects of eliminating fishery discards. Nature Commun. 5: $1-6$ https://doi.org/10.1038/ncomms4893

Hordyk A., Ono K., Valencia S., et al. 2014. A novel length-based empirical estimation method of spawning potential ratio (SPR), and tests of its performance, for small-scale, data-poor fisheries. ICES J. Mar. Sci. 72: 217-231. https://doi.org/10.1093/icesjms/fsu004

Lleonart J., Maynou F. 2003. Fish stock assessments in the Mediterranean: state of the art. Sci. Mar. 67 (Suppl. 1): 37-49. https://doi.org/10.3989/scimar.2003.67s137

Macdonald P.D.M., Green P.E.J. 1988. User's Guide to Program MIX: An Interactive Program for Fitting Mixtures of Distributions. Ichthus Data Systems, Ontario. 58 pp. http://ms.mcmaster.ca/peter/mix/MIX23 Users Guide.pdf

Macher C., Boncoeur J. 2010. Optimal selectivity and effort cost a simple bioeconomic model with an application to the Bay of Biscay Nephrops fishery. Mar. Res. Econ. 25: 213-232. https://doi.org/10.5950/0738-1360-25.2.213

Maynou F. 2014. Co-viability analysis of Western Mediterranean fisheries under MSY scenarios for 2020. ICES J. Mar. Sci. 71: 1563-1571. https://doi.org/10.1093/icesjms/fsu061

Maynou F., Gil M.M., Vitale S., et al. 2018. Fishers' perceptions of the European Union discards ban: perspective from south European fisheries. Mar. Pol. 89: 147-153 https://doi.org/10.1016/j.marpol.2017.12.019

Prellezo R., Carmona I., García D. 2016. The bad, the good and the very good of the landing obligation implementation in the Bay of Biscay: A case study of Basque trawlers. Fish. Res. 181: $172-185$. https://doi.org/10.1016/j.fishres.2016.04.016

Prellezo R., Carmona I., García D., et al. 2017. Bioeconomic assessment of a change in fishing gear selectivity: The case of a single-species fleet affected by the landing obligation. Sci. Mar. 81: $371-380$ https://doi.org/10.3989/scimar.04597.18A

Sartor P., Carbonara P., Lucchetti A., et al. 2016. Indagine conoscitiva sullo scarto della pesca alle specie demersali nei mari italiani. Valutazioni propedeutiche per l'implementazione delle disposizioni comunitarie in tema di obbligo di sbarco. Quaderni Nisea. 1, $40 \mathrm{pp}$

Scott R.D., Sampson D.B. 2011. The sensitivity of long-term yield targets to changes in fishery age-selectivity. Mar. Pol. 35: 79-84. https://doi.org/10.1016/j.marpol.2010.08.005

Shepherd J.G., Pope J.G. 2002. Dynamic pool models I: Interpreting the past using Virtual Population Analysis. In: Hart P.J.B., Reynolds J.D., Handbook of Fish Biology and Fisheries, vol. 2: 127-163. Blackwell Science Ltd.

Scientific, Technical and Economic Committee for Fisheries (STECF). 2013. Assessment of Mediterranean Sea stocks part I (STECF 13-22). Publications Office of the European Union, Luxembourg, EUR 26329 EN, JRC 86087, 400 pp.

Scientific, Technical and Economic Committee for Fisheries (STECF). 2014. Assessment of Mediterranean Sea stocks - part 1 (STECF-14-17). Publications Office of the European Union, Luxembourg, EUR 26955 EN, JRC 93120, 393 pp.

Scientific, Technical and Economic Committee for Fisheries (STECF). 2015a. Mediterranean Assessments part 2 
(STECF-15-06). Publications Office of the European Union, Luxembourg, EUR 27221 EN, JRC 95822, 396 pp.

Scientific, Technical and Economic Committee for Fisheries (STECF). 2015b. Mediterranean assessments part 1 (STECF-15-18). Publications Office of the European Union, Luxembourg, EUR 27638 EN, JRC 98676, 410 pp.

Scientific, Technical and Economic Committee for Fisheries (STECF). 2016. The 2016 Annual Economic Report on the EU Fishing Fleet (STECF 16-11). Publications Office of the European Union, Luxembourg.

Scientific, Technical and Economic Committee for Fisheries (STECF). 2017. Mediterranean assessments 2016- part 2
(STECF-17-06). Publications Office of the European Union, Luxembourg; EUR 28359 EN.

https://doi.org/10.2760/015005

Sola I, Maynou F. 2018. Assessment of the relative catch performance of hake, red mullet and striped red mullet in a modified trawl extension with T90 netting. Sci. Mar. 82S1: 19-26. https://doi.org/10.3989/scimar.04711.04A

Tsagarakis K., Palialexis A., Vassilopoulou V. 2014. Mediterranean fishery discards: review of the existing knowledge. ICES J. Mar. Sci. 71: 1219-1234.

https://doi.org/10.1093/icesjms/fst074 